\title{
The effect of rice types on chao properties during fermentation
}

\author{
Meysi Azkiyah $^{1 *}$, Amran Laga $^{1}$, Meta Mahendradatta ${ }^{1}$ and Riku Shimomura ${ }^{2}$ \\ ${ }^{1}$ Department of Agricultural Technology, Hasanuddin University, Makassar, Indonesia \\ ${ }^{2}$ Faculty of Agriculture, Kagawa University, Japan
}

\begin{abstract}
Chao is a typical Indonesian dish from Pangkep Regency that is relatively unknown to the general public. Chao is made from fermented fish, which is subsequently fermented with rice. Chao has the properties of pasta-like, light-brown color, unique flavor, slightly acidic and salty taste. Pangkep communities typically use chao as a seasoning, condiment ingredient, or as a side dish. Due to the product's attractive features, which resemble stale food, make it less appealing to consumers. It necessitates innovation and processing technologies in order to improve the quality of Chao products. This research aimed to find out the effect of rice variations including white rice, red rice and black rice on the characteristics of Shrimp Chao during fermentation. The testing parameters in this study were total Lactic Acid Bacteria (LAB), total lactic acid, $\mathrm{pH}$, and organoleptic. The highest LAB growth was found in the red rice that is $7.67 \mathrm{log} \mathrm{cfu} / \mathrm{g}$ with the lowest $\mathrm{pH}$ value of 6.02 and the highest lactic acid content (1.8\%). The best organoleptic test results own by white rice-based shrimp chao with preference average score of 3.85 and red rice 3.78 which imply "like" in organoleptic scale scoring.
\end{abstract}

\section{Article History}

Received Jan 31, 2021

Accepted Oct 10, 2021

\section{Keyword}

Lactic acid bacteria, Indonesian Traditional Food, Shrimp

\section{Introduction}

Chao is a traditional Indonesian food from Pangkajene dan Kepulauan (Pangkep) in South Sulawesi that is not commonly known by the general public. This traditional delicacy is made from fermented fish and white rice. The type of fish that are commonly used in Chao production is low-value fish such as anchovies (Teri). However, shrimp is occasionally used as well. Pangkep communities typically use Chao as a seasoning, condiment ingredient, or as a side dish. Chao has the properties of pasta-like, light-brown color, unique flavor, slightly acidic, and salty taste (1).

Several studies have revealed that Chao products contain a variety of probiotic lactic acid bacteria (2-4), which can provide various health benefits (5). These bacteria naturally come from the fish muscle used as raw material in Chao production. A study by Nurhikmayani (2018) identified two types of lactic acid bacteria from Chao products, i.e., Lactobacillus plantarum and Pediococcus pentosaceus (3). The growth of lactic acid bacteria during Chao production can be influenced by the availability of sugar or carbohydrates, $\mathrm{pH}$, temperature, water activity, and the presence of oxygen. Lactic acid bacteria will thrive in environments that can provide an adequate supply of sugar since almost all types of $L A B$ derive their energy from sugar metabolism (6). Besides the presence of the probiotic bacteria, fermented fish such as Chao are also reported to have several health benefits like 
dipeptides to lower blood pressure and induce insulin secretion (7), antioxidant scavenging capability, and improve appetite (8) that makes it good to be consumed widely.

At the moment, Chao is uncommon in the community. This is because the product's attractive features, which resemble stale food, make it less appealing to consumers. This necessitates the enhancement of Chao products' quality through innovation and processing technologies. Thus, it will increase its organoleptic acceptability, allowing more people to benefit from Chao's health benefits. One option to incorporate innovation is to change the type of rice used, such as replacing it with aromatic rice, which has a more palatable flavor for consumers, such as red and black rice. However, to our knowledge, no study of the types of rice used in Chao production has been conducted. Therefore, this study aimed to find out the effect of rice variations, including white rice, red rice, and black rice on the characteristics of Shrimp Chao during fermentation. The variation of aromatic rice as a source of sugar is expected to increase the growth of lactic acid bacteria in the production of Shrimp Chao. In addition, Chao, made with aromatic rice, was hoped to have a distinctive taste and aroma.

\section{Materials and Methods}

Materials used, which include Vaname shrimp (Litopenaeus vannamei), white rice, red rice, black rice, tape yeast, and salt, were purchased from the local market. Chemical reagents used for analysis were $\mathrm{NaOH} 0.1 \mathrm{~N}$, ethanol 70\%, Man Rogosa Sharpe Agar (MRSA) (Merck), and $\mathrm{CaCO}_{3}$.

\subsection{Chao Production Procedure}

The shrimps were peeled, washed, stored in an airtight container, and fermented for seven days. The rice was cleaned and then steamed until cooked. The cooked rice was added to the fermented shrimp and mixed thoroughly. One percent $(\mathrm{w} / \mathrm{w})$ yeast was added to the mixture and stirred. Then fermentation process was continued for seven days (1). During the second stage of fermentation, $\mathrm{pH}$ was measured, lactic acid content, total lactic acid bacteria, and total yeast was analyzed on days 3,5 , and 7 .

\subsection{Lactic Acid Bacteria}

Prior to the Lactic Acid Bacteria (LAB) count, the agar media (MRSA) and physiological solution were prepared. MRSA media were dissolved in distilled water with the addition of $1 \%$ of $\mathrm{CaCO}_{3}$. The media was homogenized using a magnetic stirrer on a hot plate. The media and the physiological solution were sterilized in an autoclave at $121^{\circ} \mathrm{C}$ for 15 minutes. One gram of fermented sample was dissolved in $9 \mathrm{ml}$ of physiological solution to obtain the $10^{-1}$ dilution. Serial dilutions to $10^{-7}$ were performed. Plating was carried out from the $10^{-5}$ to $10^{-7}$ dilutions using the pour plate method in which $1 \mathrm{ml}$ of diluted samples were inoculated to sterile Petri dishes, then warm MRSA was added into the Petri dishes and incubated for 48 hours at $37^{\circ} \mathrm{C}$. Total lactic acid bacteria was determined using equation 1 :

$$
\begin{aligned}
& N=\frac{\sum C}{\{(1 \times n 1)+(0.1 \times n 2)\} \times(d)} C \\
& N=\text { Colony Forming Units } \\
& \Sigma C=\text { The total number of colonies were counted }
\end{aligned}
$$


$\mathrm{n} 1=$ The number of colonies on the first dilution

$\mathrm{n} 2=$ The number of colonies on the second dilution

$d=$ The first dilution level that counted

\subsection{Total Lactic Acid}

The determination of total lactic acid was carried out using the acid-base titration method (9). A total of 10 grams of sample was crushed with a mortar, then placed in a 100 $\mathrm{ml}$ Erlenmeyer. Distilled water was added to the Erlenmeyer until it reached the desired volume, then homogenized and filtered. Ten $\mathrm{mL}$ of the filtrate was placed in an Erlenmeyer and added with 2-3 drops of phenolphthalein indicator, then titrated with $0.1 \mathrm{~N} \mathrm{NaOH}$ solution to form a pink color. Calculation of total acid content was performed using equation 2: (1)

$$
\begin{aligned}
& \% \text { Lactic Acid }=\frac{a \times b \times c \times d}{\mathrm{e}} 100 \% \\
\mathrm{a}= & \text { Amount of } \mathrm{NaOH} \text { needed in titration }(\mathrm{ml}) \\
\mathrm{b}= & \mathrm{NaOH} \text { normality }(0.1 \mathrm{~N}) \\
\mathrm{c}= & \text { Equivalent weight of lactic acid }(90) \\
\mathrm{d}= & \text { Dilution factor } \\
\mathrm{e}= & \text { Sample weight }
\end{aligned}
$$

\section{4. pH Measurement}

Five $\mathrm{g}$ of sample was dissolved in $5 \mathrm{ml}$ of distilled water and shaken until homogenous. $\mathrm{PH}$ of the solutions was measured using a pre-calibrated $\mathrm{pH}$ meter.

\subsection{Organoleptic Test}

The shrimp-based Chao products obtained from this study were organoleptically tested for color, taste, aroma, and texture by 15 semi-trained panelists. An organoleptic test was carried out using the five points Hedonic Scale. The scale of the hedonic score used is presented in table 1.

Table 1. Test of Organoleptic Scale

\begin{tabular}{lc}
\hline Hedonic Scale & Numeric Scale \\
\hline Like very much & 5 \\
Like & 4 \\
Like moderately & 3 \\
Dislike & 2 \\
Dislike very much & 1 \\
\hline
\end{tabular}

\section{Results and Discussion}

\subsection{Lactic Acid Bacteria}

Lactic acid bacteria (LAB) are a group of Gram-positive spore-forming bacteria that can ferment carbohydrates to produce lactic acid (10). In this study, total LAB represents the total population of $L A B$ in each sample. The effects of rice types and the length of 
fermentation on total lactic acid bacteria in fermented Shrimp Chao are presented in Figure 1.

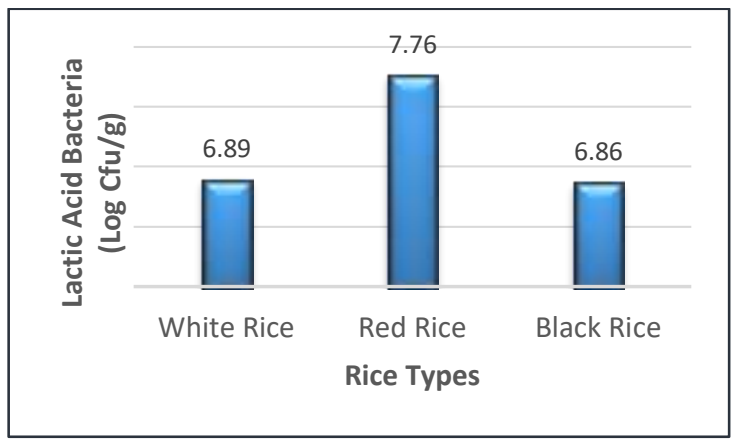

(a)

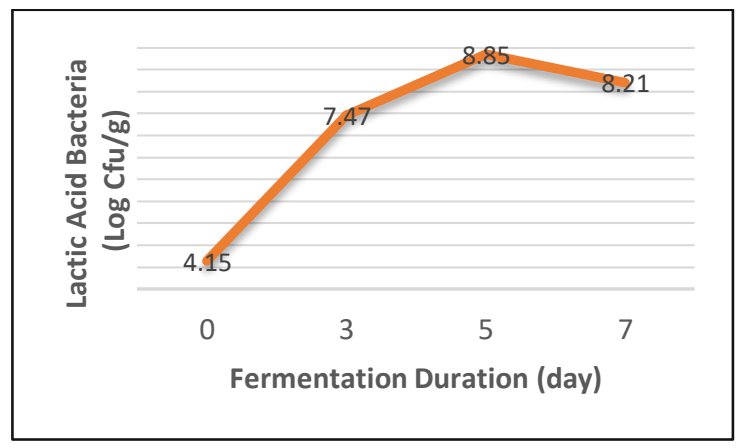

(b)

Figure 1. Total Lactic Acid Bacteria (Log cfu/g) of Shrimp Chao

Figure 1a illustrates that $L A B$ count in Chao made from red rice (7.76 log Cfu/g) was significantly higher than those of the other treatments. Red rice contains a high amount of protein (7.45\%) (11) which can function as a nitrogen source that is required for the growth of LAB. This is in accordance with the generally known fact that basic nutrients needed by bacteria during their growth are nitrogen, carbon, and minerals (12).

Based on Figure $1 b$, it can be seen that the $L A B$ growth tended to increase from day 0 to day 5 of fermentation and decreased on day 7. The growth of LAB on day 0 was $4.15 \log$ $\mathrm{Cfu} / \mathrm{g}$ and continued to increase until day 5 of fermentation which was $8.85 \mathrm{log} \mathrm{Cfu} / \mathrm{ml}$. The LAB count decreased to $8.21 \mathrm{log} \mathrm{Cfu} / \mathrm{g}$ on day seven fermentation due to the fact that LAB had entered the stationary phase.

\subsection{Total Lactic Acid}

Lactic acid or 2-hydroxypropanoic acid $\left(\mathrm{CH}_{3} \mathrm{CHOHCOOH}\right)$ is a chemical compound that is widely used in industry. These compounds are used, among other things, as additional ingredients in food products, namely as an acidity regulator, flavor enhancer, and as an inhibitor of pathogenic bacteria in meat products. Lactic acid can be produced by lactic acid bacteria with a purity level of $90-95 \%$ (13). Lactic acid production generally begins with glucose metabolism by LAB. The glucose in Chao products is probably produced from the breakdown of complex carbohydrates in rice by the consortium of microbes which may contain Aspergillus sp. Based on the result reported by Souza, 2010 (14), it was indicated that Aspergillus sp. was the microbes responsible for starch breakdown for glucose production.

The results of total lactic acid in fermented Shrimp Chao obtained ranged from 1.55 to $1.81 \%$. The effect of rice types and length of fermentation on total lactic acid in Chao fermentation can be seen in Figure 2. 


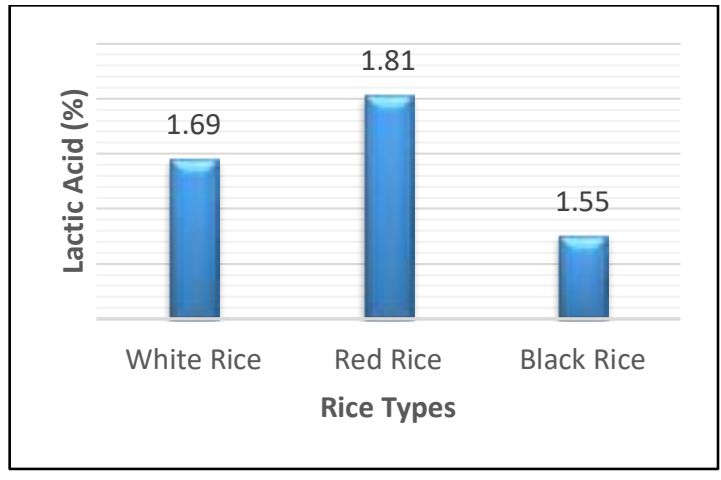

(a)

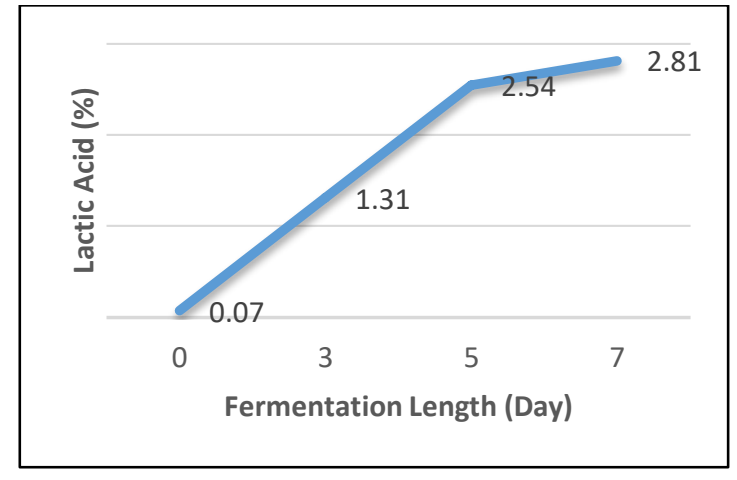

(b)

Figure 2. Total Lactic Acid (\%) of Shrimp Chao

The lactic acid concentrations found in this study from the three types of rice were all higher than the lactic acid concentration found in Anchovy Chao with white rice (1.20\%) (1). Moreover, the highest lactic acid content found in Chao made from a mixture of shrimp paste and red rice $(1.81 \%)$ was significantly higher than those found in Chao made from a mixture of shrimp paste and white rice $(1.69 \%)$ or black rice $(1.55 \%)$. This result seems to be related to the amount of $L A B$ count found in red rice Chao that was higher than those in white and black rice Chao. This result is in accordance with the result reported by Armanto (2008) (15), which indicated that the higher the concentration of lactic acid bacteria, the higher the total acid produced.

Figure $2 \mathrm{~b}$ depicts that the lactic acid content increased during the fermentation process, from $0.07 \%$ on day 0 to $2.81 \%$ on day 7 . This is due to the fact that the lactic acid produced during fermentation accumulated until the end of fermentation. The longer the fermentation process, the more metabolites are produced, including organic acids (15).

\section{3. $\mathrm{pH}$}

The degree of acidity $(\mathrm{pH})$ of Shrimp Chao products during fermentation was influenced by the amount of organic acid produced during fermentation.

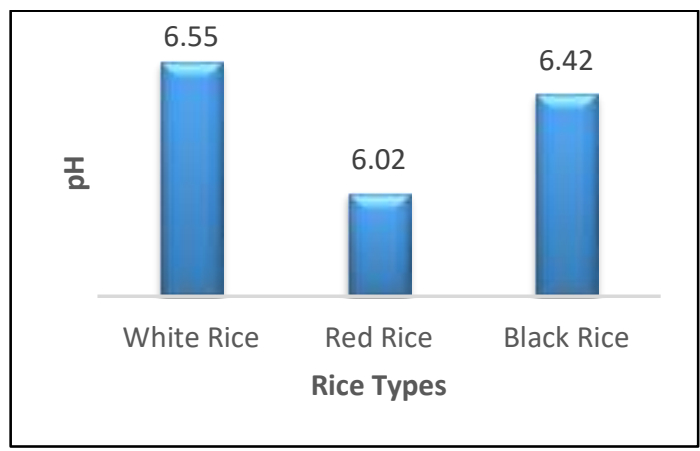

(a)

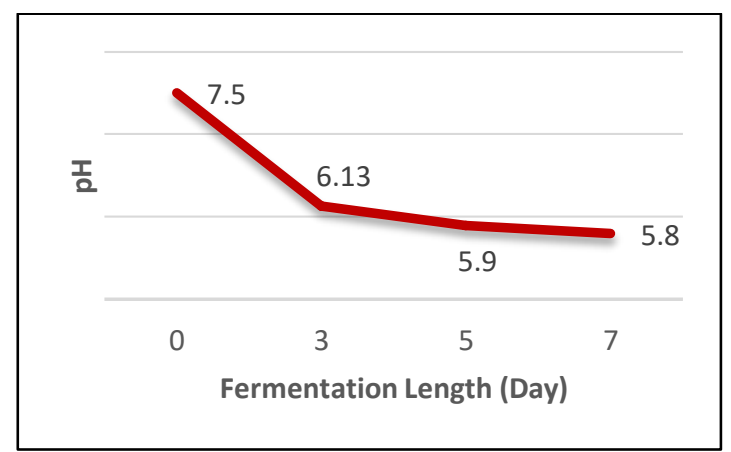

(b)

Figure 3. pH Value of Shrimp Chao

The lowest $\mathrm{pH}$ value (6.02) was found in the Chao produced from a mixture of shrimp paste and red rice. This value is significantly lower than the $\mathrm{pH}$ obtained from the other treatments. On the other hand, the highest $\mathrm{pH}$ value (6.55) was found in Chao produced from the mixture of shrimp paste and white rice. This result shows that the acid compounds 
produced in shrimp paste and red rice are higher than the acid compounds produced from shrimp Chao using the other types of rice. This is consistent with the result shown in Figure 2.

The $\mathrm{pH}$ of fermented fish and rice mixtures like Chao was not only influenced by the production of lactic and acetic acids by LAB but was also influenced by other organic compounds produced from fermentation. Susanto (2006) found that glutinous rice fermented using yeast produced $0.08 \%$ ethanol. Ethanol is a chemical substance that is acidic, so it can affect the $\mathrm{pH}$ value of the fermented product $(16,17)$.

\subsection{Organoleptic Test}

Acceptability of any food product largely depends on several characteristics, including sensory. To assess consumer acceptability of shrimp Chao produced in this study, the sensory test was conducted by 15 semi-trained panelists using five scales hedonic. Average scores of sensory parameters are given in table 2.

Table 2. The Result of Organoleptic Test on Shrimp Chao

\begin{tabular}{cccccc}
\hline Rice Type & Color & Taste & Aroma & Texture & Average \\
\hline White Rice & 4.07 & 3.8 & 3.53 & 4 & 3.85 \\
Red Rice & 3.63 & 3.9 & 3.8 & 3.77 & 3.78 \\
Black Rice & 2.73 & 2.97 & 2.67 & 3.3 & 2.92 \\
\hline
\end{tabular}

Table 2 shows that the type of rice affects the level of panelists' preference for Chao Shrimp products. The overall result of the sensory test suggested that the panelist preferred shrimp chaos made from a mixture of shrimp paste and white rice. In particular, hedonic scores for color and texture were highest for Chao produced from a mixture of shrimp paste and white rice. However, hedonic scores for taste and aroma were highest for Chao produced from a mixture of shrimp paste and red rice. The hedonic scores indicated that the Chao made from a mixture of shrimp paste and red rice was relatively more preferred by panelists compared to Chao made from the mixture of shrimp paste and black rice.

The use of red and black rice in this study was intended to increase the nutritional and functional properties of shrimp Chao. Several studies have indicated that red and black rice contained high amounts of anthocyanin (18-22). However, the hedonic scores indicated that the likeness levels for shrimp chaos from black rice were relatively low. Therefore, the method of rice preparation should be altered when using black rice in order to produce Chao with a better texture. In order to improve the acceptance of aroma, a flavoring agent might be needed. In addition, consumer education is necessary to ensure that consumers understand that the black hue signifies a high concentration of beneficial health compounds such as anthocyanin.

\section{Conclusions}

The highest $L A B$ count was found in the Chao made from a mixture of shrimp paste and red rice. The red rice Shrimp Chao also has the lowest $\mathrm{pH}$ value and the highest lactic acid content. The best organoleptic test results were found in Chao produced from white rice with an average preference score of 3.85, and red rice with an average preference score 
of 3.78, both of which indicate "like" in the organoleptic scale. The use of black rice in Chao formulation resulted in a lower acceptance level using the current production method.

\section{Acknowledgements}

This research fund was provided by PT. Indofood Makmur Tbk. by Indofood Riset Nugraha (IRN) 2019/2020 program.

\section{Author Contributions}

Meysi Azkiyah and Amran Laga conceived and designed the experiments; Meta Mahendradatta, and Riku Shimomura performed the experiments; Meysi Azkiyah the data; Meysi Azkiyah contributed reagents/materials/analysis tools; Meysi Azkiyah wrote the paper.

\section{References}

1. Syahriati M, Laga A, Thahir MM, Zaraswati Dwyana D. Chemical Characteristic of "Chao teri" As Traditional Fermentation Product. Int J Sci Res Sci Technol. 2019;6(4):160-6.

2. Matti A, Utami T, Hidayat C, S. Rahayu E. Isolation, Screening, and Identification of Proteolytic Lactic Acid Bacteria from Indigenous Chao Product. J Aquat Food Prod Technol. 2019;28(7):781-93.

3. Nurhikmayani R, Daryono BS, Retnaningrum E. Isolation and molecular identification of antimicrobial-producing lactic acid bacteria from chao, South Sulawesi (Indonesia) fermented fish product. Biodiversitas. 2019;20(4):1063-8.

4. Zielińska D, Kolozyn-Krajewska D, Laranjo M. Food-Origin Lactic Acid Bacteria May Exhibit Probiotic Properties: Review. Biomed Res Int. 2018;2018.

5. FAO/WHO. Guidelines for the Evaluation of Probiotics in Food. 2002. 1-11 p.

6. Saeed A H, Salam A I. Current limitations and challenges with lactic acid bacteria: a review. Food Nutr Sci. 2013;2013(November):73-87.

7. Mouroufie AKJ, SKPAN E, Kouakou AC, Kouakou EK V, Kati-oulibaly S. Review on the study of health effects of some fermented foods consumed on Côte d'Ivoire. Glob J Biol Agric Heal Sci. 2018;7(3):1-9.

8. Uchoi D. Fermentation Technology for Fish. :123-31.

9. Feng S, Xiang S, Bian X, Li G. Quantitative analysis of total acidity in aqueous lactic acid solutions by direct potentiometric titration. Microchem J. 2020;157:105049.

10. Mokoena MP. Lactic acid bacteria and their bacteriocins: Classification, biosynthesis and applications against uropathogens: A mini-review. Molecules. 2017;22(8).

11. Gunaratne A, Wu K, Li D, Bentota A, Corke H, Cai Y-Z. Antioxidant activity and nutritional quality of traditional red-grained rice varieties containing proanthocyanidins. Food Chem. 2013;138(2-3):1153-61.

12. García-Ruiz A, Bartolomé B, Cueva C, Martín-Álvarez PJ, Moreno-Arribas M V. Inactivation of oenological lactic acid bacteria (Lactobacillus hilgardii and Pediococcus pentosaceus) by wine phenolic compounds. J Appl Microbiol. 2009;107(3):1042-53.

13. Abedi E, Hashemi SMB. Lactic acid production-producing microorganisms and substrates sources-state of art. Heliyon. 2020;6(10):e04974.

14. Souza PM de, Magalhães $P$ de $O$. Application of microbial $\alpha$-amylase in industry-A review. Brazilian J Microbiol. 2010;41:850-61. 
15. Armanto R, Nurasih A. Kajian Konsentrasi Bakteri Asam Laktat Dan Lama Fermentasi Pada Pembuatan Tepung Pati Singkong Asam. Agritech J Fak Teknol Pertan UGM. 2008;28(3):97-101.

16. Feng $Y, M a X$, Kong $B$, Chen $Q$, Liu $Q$. Ethanol induced changes in structural, morphological, and functional properties of whey proteins isolates: Influence of ethanol concentration. Food Hydrocoll. 2021;111:106379.

17. Ma X, Wang J, Gao M, Wang N, Li C, Wang Q. Effect of $\mathrm{pH}$ regulation mode on byproduct ethanol generated from the lactic acid fermentation of Sophora flavescens residues. J Clean Prod. 2021;279:123536.

18. Sumczynski $D$, Kotásková $E$, Družbíková $H$, Mlček J. Determination of contents and antioxidant activity of free and bound phenolics compounds and in vitro digestibility of commercial black and red rice (Oryza sativa L.) varieties. Food Chem. 2016;211:339-46.

19. Shao Y, Hu Z, Yu Y, Mou R, Zhu Z, Beta T. Phenolic acids, anthocyanins, proanthocyanidins, antioxidant activity, minerals and their correlations in nonpigmented, red, and black rice. Food Chem. 2018;239:733-41.

20. Wang S, Chu Z, Ren M, Jia R, Zhao C, Fei D, et al. Identification of anthocyanin composition and functional analysis of an anthocyanin activator in Solanum nigrum fruits. Molecules. 2017;22(6):876.

21. Jie Hao, Hui Zhu, Zhenqing Zhang, Shilin Yang HL. Identification of anthocyanins in black rice (Oryza sativa L.) by UPLC/Q- TOF-MS and their in vitro and in vivo antioxidant activities. J Cereal Sci. 2015;64:92-9.

22. Priska M, Peni N, Carvallo L, Ngapa YD. Antosianin dan Pemanfaatannya. Cakra Kim Indones. 2018;6(2):79-97. 